\title{
Multispectral aerial image processing system for precision agriculture
}

\author{
Samy Kharuf-Gutierrez / kharuf@uclv.cu \\ Rubén Orozco-Morales / rorozco@uclv.edu.cu
}

Universidad Central "Marta Abreu" de las Villas, Santa Clara-Cuba.

Osmany de la C. Aday Díaz / osmany.aday@inicavc.azcuba.cu

Emma Pineda Ruiz / emma.pineda@inicavc.azcuba.cu

Estación Territorial de Investigaciones de la Caña de Azúcar, Santa Clara-Cuba.

ABSTRACT Cuban agriculture has the growing need to increase its productivity. To achieve this, precision agriculture can play a fundamental role. It is necessary to develop an image processing system able to process all the crops information and calculate vegetation indexes in a satisfactory way. This will entail in accurate measurements of the nitrogen lack, the hydric stress, and the vegetal strength, among other aspects, seeking to improve the accuracy in the care of these aspects. This document reports the results of an investigation pointed to develop a procedure for capturing and processing multispectral aerial images obtained from Unmanned Aerial Vehicles [UAV]. This procedure searched to measure the vegetation indexes of sugarcane crops that may be correlated with the level of vegetal strength, the number of stems, and the foliar mass per lot. We used a USENSE-X8 UAV together with a Sequoia multispectral sensor and the QGIS processing software. The procedure was experimentally validated.

KEYWORDS Near infrared; precision agriculture; Sequoia: unmanned aerial vehicle; vegetation index.

Sistema de procesamiento de imágenes multiespectrales aéreas para agricultura de precisión

RESUMEN LLa agricultura cubana tiene la necesidad creciente de aumentar su productividad, para lograrlo, la agricultura de precisión puede desempeñar un papel fundamental. Es necesario entonces desarrollar un sistema de procesamiento de imágenes capaz de procesar toda la información de los cultivos y calcular índices vegetativos de forma satisfactoria, para así medir con precisión el déficit de nitrógeno, el estrés hídrico y el vigor vegetal, entre otros aspectos, para que la atención de estos aspectos sea también precisa. Este documento reporta los resultados de una investigación dirigida al desarrollo de un procedimiento para la toma y procesamiento de imágenes multiespectrales aéreas obtenidas desde Vehículos Aéreos No Tripulados [VANT], para obtener índices vegetativos de sembrados de caña de azúcar que puedan ser correlacionados con el nivel de vigor vegetal, el número de tallos o la masa foliar por parcela. Se utilizó un VANT USENSE-X8 y sus componentes, un sensor multiespectral Sequoia y el software de procesamiento QGIS. El procedimiento fue validado de forma experimental.

PALABRAS CLAVE Agricultura de precisión; índice vegetativo; infrarrojo cercano; Vehículo aéreo no tripulado; Sequoia.
Sistema de processamento de imagens aéreas múlti espectrais para agricultura de precisão

RESUMO A agricultura cubana tem uma necessidade crescente de aumentar sua produtividade, e para isso, a agricultura de precisão pode desempenhar um papel fundamental. É necessário, portanto, desenvolver um sistema de processamento de imagens capaz de processar toda a informação dos plantios e calcular de forma satisfatória índices de vegetação, de forma de poder medir com precisão o déficit de nitrogênio, o estresse hídrico e o vigor vegetal, entre outros aspectos, para que a atenção desses aspectos também seja precisa. Este documento relata os resultados de uma pesquisa focada ao desenvolvimento de um procedimento para a obtenção e processamento de imagens aéreas múlti espectrais obtidas desde veículos aéreos não tripulados [VANT], para obter índices de vegetação de plantios de cana-de-açúcar que podem ser correlacionados com o nível de vigor vegetal, o número de hastes ou a massa foliar por parcela. Foi utilizado um VANT USENSE-X8 e seus componentes, um sensor múlti espectral Sequoia e o software de processamento QGIS. O procedimento foi validado experimentalmente.

PALAVRAS-CHAVE Agricultura de precisão; índice de vegetação; infravermelho próximo; Veículo aéreo não tripulado; Sequoia. 


\section{Introduction}

During the last years, the availability in the natural resources such as water, air, and soil has been reduced in quality and quantity; on the other hand, the climatic variability has been increased and this has caused several economic losses to both small and large agricultural actors in Cuba. Likewise, the insufficient planning of the crops in most parts of the agricultural Cuban sector joined with the cost overruns associated with the diseases attention and the poor technical assistance have entailed effects involving low competitivity of the national agricultural sector and low market penetration of Cuban products in the international markets, where high quality standards related with a low use of agrochemical materials and sustainable practices are required.

There is a large need to implement efficient and precise techniques in agriculture, since that will lead tothe producers to reduce their supplies expenses and will increase the yield production (Saxena \& Armstrong, 2014). The so-called Precision Agriculture [PA] is an agronomic concept related with crop field management based on the analysis of the crop variability, where its implementation implies the use of current technologies such as Global Positioning Systems [GPS]; sensors; satellites and aerial images; Geographic Information Systems [GIS]; among others to estimate, assess, and understand such variations (Marote, 2010).

Within PA, a cycle of agricultural practices is implemented that replaces the current supplies recommendation where their amounts are calculated based on average values - , with another one where the formulated amounts are more precise through a localized treatment and considering the yield variations in all the cultivated area. In consequence, $\mathrm{PA}$ is focused on the optimization of the resources usage by locating in the soil the number of seeds that each point supports together with the right amount of supplies and water. Furthermore, the weed control is performed only where required and not indiscriminately (Best \& Zamora, 2008).

The multispectral photogrammetry is one of the main tools for PA, it is a passive technique (in the infrared range between 0.76 and $14 \mu \mathrm{m}$ ) focused on water, element affecting the technical properties of the plants; this makes this technique useful where the leaf has several amount of water per surface unit (Vibhute \& Bodhe, 2012).

The crop monitoring activity from the imagegathering of has been performed by using sensors transported in the air via manned and unmanned vehicles ( Guo, Kujirai, \& Watanabe, 2012; Torres, Gómez, \& Jimenez, 2015; Campo, Corrales, \& Ledezma, 2015), which entails advantages relative to the use of satellite images. This last because satellite images do not have the temporal and spatial resolution that the crop monitoring activity requires; furthermore,

\section{Introducción}

En los últimos años, la disponibilidad de recursos naturales, tales como el agua, el aire y el suelo, se ha reducido en calidad y cantidad, mientras que la variabilidad climática ha aumentado y provocado cuantiosas pérdidas económicas a grandes y pequeños productores agrícolas en Cuba. Asimismo, la insuficiente planificación de los cultivos de la mayor parte del sector agrícola cubano, los sobrecostos asociados con la atención de enfermedades y la pobre asistencia técnica han desencadenado efectos que se traducen en una baja competitividad del sector agrícola nacional y una escaza inserción de sus productos en los mercados internacionales, donde se requiere de altos estándares de calidad relacionados con un menor empleo de agroquímicos y un manejo sostenible del sistema productivo.

Existe una gran necesidad de implementar técnicas eficientes y precisas en la agricultura, pues ellas le permitirían a los productores un gasto mínimo de insumos y una alta producción (Saxena \& Armstrong, 2014). La Agricultura de Precisión [AP] es un concepto agronómico de gestión de campos de cultivo basado en el análisis de la variabilidad del cultivo, su implementación implica el uso de tecnología actual: sistema de posicionamiento global [Global Positioning System, GPS], sensores, satélites e imágenes aéreas, sistemas de información geográfica [Geographic Information Systems, GIS], entre otras, para estimar, evaluar y entender dichas variaciones (Marote, 2010).

En la AP se implementa un ciclo de prácticas agrícolas que sustituye la recomendación habitual de insumos - donde sus cantidades son calculadas con base en valores promedio-, con otra donde las cantidades formuladas son más exactas, a partir de un manejo localizado y considerando las variaciones del rendimiento en toda la zona cultivada. Se trata, en consecuencia, de la optimización del empleo de los recursos, en la medida en que deposita en el suelo solo la cantidad de semilla que cada punto soporta y la cantidad de nutrientes y agua necesarias, y realiza el control de maleza, plagas y enfermedades únicamente donde se requiere (Best \& Zamora, 2008).

La fotogrametría multiespectral es una de las herramientas fundamentales para la AP, ella es una técnica pasiva (rango infrarrojo entre 0.76 y 14 micras) que se centra en el agua, elemento que afecta las propiedades térmicas de las plantas y hace posible su utilización en cultivos donde la hoja contiene diferentes cantidades de agua por unidad de superficie (Vibhute \& Bodhe, 2012).

El monitoreo de los cultivos a partir de la recolección de datos de imagen se ha realizado empleando sensores aerotransportados mediante plataformas tripuladas y no tripuladas (Guo, Kujirai, \& Watanabe, 2012; Torres, Gómez, \& Jimenez, 2015; Campo, Corrales, \& Ledezma, 2015), lo que tiene ventajas frente al uso de imágenes satelitales, ya que aquellas no poseen la resolución espacial y temporal que requiere el monitoreo de un cultivo, además de que los datos recolectados pueden ser inadecuados debido a factores atmosféricos - como la presencia de nubes-, que dificultan la observación de la cobertura a nivel del suelo. Las imágenes tomadas desde plataformas aéreas suplen entonces las necesidades de obtención inmediata de imágenes 
con características superiores a obtenidas a través de satelitales (Basso, 2014; Gago et al., 2015; Hernández et al., 2016).

Las imágenes multiespectrales recopiladas utilizando Vehículos Aéreos No Tripulados [VANT] permiten obtener índices vegetativos [IV], que no son más que combinaciones algebraicas de varias bandas espectrales, diseñadas para resaltar el vigor y las propiedades de la vegetación, como son: la biomasa de la canopia, la radiación absorbida y el contenido de clorofila (Gutiérrez-Rodriguez, Escalante-Estrada, \& Rodriguez-Gonzalez, 2005). El cálculo de diferentes índices vegetativos permite interpretar la información de las imágenes NIR [Near Infrared Spectroscopy] y RGB [Red Green Blue] captadas mediante técnicas de fotogrametría, mostrando el NDVI [Normalized Difference Vegetation Index], el vigor de las plantas; el GNDVI [Green Normalized Difference Vegetation Index], el nivel de nitrógeno; el CWSI [Crop Water Stress Index], el nivel de estrés hídrico de las plantas; y el SAVI [Soil Adjusted Vegetation Index] un ajuste de los estudios agronómicos al tipo de suelo en las plantaciones (Candiago, Remondino, De Giglio, Dubbini, \& Gattelli, 2015).

Informes anteriores han documentado la capacidad de los índices vegetativos para estimar el potencial de rendimiento de la caña de azúcar, sin embargo, la mayoría de ellos se ha centrado en el uso de plataformas basadas en satélites o sensores pasivos (Lofton et al., 2012; Zhao et al., 2016; Johansen et al., 2017; Martínez, 2017) y muy pocos en demostrar la capacidad de un sensor remoto activo en tierra para estimar variables de interés agrícola en campos de caña de azúcar en zonas tropicales.

En la industria azucarera cubana hay un creciente interés por la aplicación de tecnologías de agricultura de precisión con fines productivos. Poder delimitar ambientes con diferente potencial productivo en un mismo campo de caña sería un buen comienzo para la implementación del manejo sitio-específico en este cultivo a nivel nacional.

Este trabajo tiene como objetivo realizar un levantamiento fotogramétrico multiespectral, utilizando VANT en las áreas de la Estación Territorial de Investigaciones de la Caña de Azúcar [ETICA] para la elaboración de mapas de índices vegetativos que permitan evaluar el vigor vegetal y la masa foliar de parcelas de caña de azúcar sembradas en suelos del tipo vertisol pélico, en condiciones de secano y bajo un clima tropical.

\section{II. Índices vegetativos}

Los IV más usados y derivables de un sensor multiespectral tribanda son: NDVI, GNDVI y SAVI (Candiago et al., 2015). Los investigadores en estudios sobre la vegetación explotan que la reflectancia en las regiones azules y rojas del espectro es baja (Bachmann, Herbst, Gebbers, \& Hafner, 2013), mientras que en la región verde se presenta un pico. En el rango infrarrojo, la reflectancia es mucho mayor que en la banda visible, como se aprecia en la Figura 1.

El NDVI es un concepto que integra el contraste de la alta absorbancia (baja reflectancia) de la banda roja del espectro visible, con la alta reflectancia del infrarrojo cercano, como lo indica la Ecuación 1. data can be affected by meteorological aspects — such as the presence of clouds - complicating the observation of the coverage at the ground level. The images taken from aerial platforms comply with the need of immediate image gathering with superior characteristics than the ones obtained from satellites (Basso, 2014;Gago et al., 2015;Hernández et al., 2016).

The multispectral images obtained by using Unmanned Aerial Vehicles [UAV] allow the obtaining of vegetation indexes [VI], where these last are algebraic combinations of several spectral bands designed to highlight the strength and properties of the vegetation such as the biomass, absorbed radiation, and the chlorophyll content (Gutiérrez-Rodriguez, Escalante-Estrada, \& Rodriguez-Gonzalez, 2005). The calculation of several VI allows to understand the information of the Near Infrared Spectroscopy [NIR] and Red Green Blue [RGB] images obtainedby using photogrammetry techniques. Some of the achieved parameters using this technique are the Normalized Difference Vegetation Index [NDVI], plant strength, Green Normalized Difference Vegetation Index [GNDVI], nitrogen level, Crop Water Stress Index [CWSI, and Soil Adjusted Vegetation Index[SAVI]. This last is an adjustment of the agronomic studies to the soil type in the crops(Candiago, Remondino, De Giglio, Dubbini, \& Gattelli, 2015).

Previous research works have documented the capability of vegetation indexes to estimate the potential crop yield of the sugarcane; nevertheless, most of them have been focused on the use of satellite and passive sensors platforms (Lofton et al., 2012; Zhao et al., 2016; Johansen et al., 2017;Martínez, 2017)and very few have demonstrated the ability of an active remote sensor on the ground to estimate variables of interest in a sugarcane crop located in a tropical zone.

Within the Cuban sugar company, there is a growing interest for the application of PA techniques looking foran increase in the crop yields. Be able to delimitate environments with several productive potentials in a same sugarcane field would be a good starting point for the implementation of the site-specific handling in this crop.

The main objective of this work is to perform a multispectral photogrammetry work by using an UAV in the fields of the Territorial Research Station of the Sugarcane [ETICA, Estación Territorial de Investigaciones de la Caña de Azúcar] to elaborate maps with vegetation indexes allowing to assess the vegetal strength and the foliar mass of sugarcane crops sown in a pellic vertisol soil in dry conditions and under a tropical weather.

\section{Vegetation Indexes}

The four VI most employed and derivable from a tri-band multispectral sensor are NDVI, GNDVI, and SAVI (Can- 


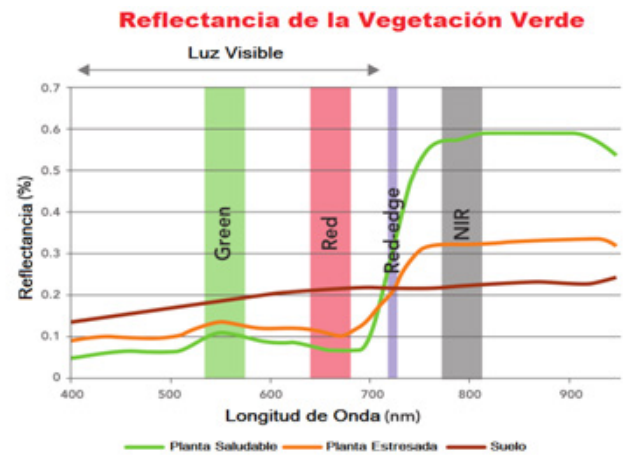

Figure 1. Reflectance of the green vegetation depending on its strength / Reflectancia de la vegetación verde según su vigor

diago et al., 2015). The research works related with these indexes indicate that the reflectance in the blue and red zones of the spectrum are low (Bachmann, Herbst, Gebbers, \& Hafner, 2013), whilst in the green region, a peak is observed. Within the infrared range, the reflectance is higher than in the visible band, as Figure 1 presents.

The NDVI is a concept integrating the contrast of the high absorbance (low reflectance) in the red band of the visible spectrum with the high reflectance of the near infrared, such as Equation 1 presents.

$$
N D V I=\frac{N I R-R}{N I R+R}
$$

where:

$\mathcal{N I R}=$ spectral value of the near infrared band; and

$R=$ spectral value of the red band.

The NDVI values are between -1 and 1 , in this range, a value near 1 corresponds to a vegetal specimen with high strength and a value of -1 to areas without vegetation such water, ice, sand, snow, or clouds - (Best, León, \& Claret, 2005; Chuvieco, 2000). The common range for vegetation is from 0.2 to 0.9 as follow: 0.2 to 0.3 for brushes and grass; and 0.4 to 0.9 for forests and crops (Pettorelli et al., 2005). Due to the ease of use and its relation with many parameters of the ecosystem, the NDVI usage has been generalized in several ecosystems for supervising labors related with the vegetation dynamics or phonologic changes of plants through time, with the biomass production, with the changes in the pasture conditions, and with the classification of the soil occupancy and moisture (Virlet, Costes, Martínez, Kelner, \& Regnar, 2015;Lopes \&Reynolds, 2012;García \& Herrera, 2015).

On the other hand, the GNDVI is an index of the "green" plant or its photosynthetic activity commonly used to determine the water absorption and the nitrogen in the crop foliage. This index is defined by Equation 2.

$$
G N D V I=\frac{N I R-\text { green }}{N I R+\text { green }}
$$

$$
N D V I=\frac{N I R-R}{N I R+R}
$$

donde:

$\mathcal{N I R}=$ valor espectral de la banda infrarroja cercana; $\mathrm{y}$

$R=$ valor espectral de la banda roja.

Los valores del NDVI toman valores entre - 1 y 1 , en ese rango, un valor cercano a 1 corresponde a una especie vegetal con alto vigor y un valor cercano a -1 a áreas sin vegetación, como agua, hielo, arena, nieve o nubes (Best, León, \& Claret, 2005; Chuvieco, 2000). El rango común para la vegetación es de 0.2 a 0.9: 0.2 a 0.3 para arbustos y césped; y de 0.4 a 0.9 , para bosques y cultivos (Pettorelli et al., 2005). Debido a su facilidad de uso y a su relación con muchos parámetros del ecosistema, el NDVI su uso se ha generalizado en distintos ecosistemas en labores de supervisión de la dinámica de la vegetación o cambios fenológicos de las plantas a través del tiempo, la producción de biomasa, los cambios en la condición de pastizales, la clasificación de la ocupación del suelo y la humedad del suelo (Virlet, Costes, Martínez, Kelner, \& Regnar, 2015; Lopes \& Reynolds, 2012; García \& Herrera, 2015).

El GNDVI, por su parte, es un índice de la planta "verde" o de la actividad fotosintética comúnmente utilizado para determinar la absorción de agua y el nitrógeno en el follaje del cultivo. El mismo se define por la Ecuación 2.

$$
G N D V I=\frac{N I R-\text { green }}{N I R+\text { green }}
$$

donde:

$\mathcal{N I R}=$ valor espectral de la banda infrarroja cercana; $\mathrm{y}$

verde $=$ valor espectral de la banda verde

El GNDVI sustituye a la banda de color rojo (R) de la recolección de datos para NDVI y lo hace con una banda muy específica de la luz en el rango verde, con lo que puede obtener información útil adicional. Mientras que índices como el NDVI no se pueden determinar sin una banda roja, índices de vegetación alternativos - como el GNDVI- tienen un contenido de información y valor similar y no necesitan de ella ( Gitelson, Kaufman, \& Merzlyak, 1996).

La obtención de GNDVI frecuentes permite la optimización del riego e indica cuándo se produce aislamiento del agua o cuando ella varía a través del campo. Esta información puede ser utilizada, junto con el GPS, para: determinar soluciones eficaces en las áreas problemáticas del cultivo, ayudar a proporcionar material de aplicación y corrección para hacer más uniformes los campos en la retención y la utilización del agua; e implementar una técnica de difusión de tasa variable precisa (Dennis, Wright, \& Philip, 2003; Hunt et al., 2010).

Algunas variaciones, como el SAVI (Huete, 1988) y el OSAVI [Optimized Soil Adjusted Vegetation Index] (Rondeaux, Steven, \& Baret, 1996), han sido formuladas para minimizar el impacto del suelo en el cálculo de los IV en aquellas áreas donde la cobertura vegetativa es pobre y la superficie del suelo está expuesta. Estas variaciones son parte de los índices de vegetación comúnmente utilizados en aplicaciones de teledetección, junto 
con el Índice de Vegetación Normalizada ( Salamí, Barrado, \& Pastor, 2014; Trotter, Frazier, Trotter, \& Lamb, 2008; Hatfield \& Prueger, 2010). El SAVI varía en el rango de -1 a 1; valores tendientes a -1 corresponden a una baja cobertura de la vegetación verde y, en consecuencia, valores tendientes a 1 , alta cobertura, su cálculo se hace utilizando la Ecuación 3.

$$
S A V I=\frac{(N I R-R) *(L+1)}{N I R+R+L}
$$

donde:

$\mathcal{N I R}=$ valor espectral de la banda infrarroja cercana;

$R=$ valor espectral de la banda roja; y

$L=$ factor de corrección de la reflectancia del suelo.

Cabe precisar que $L$ es un parámetro con valores extremos que van de -1 a 1 , donde -1 se utiliza en áreas con una cobertura de vegetación muy densa y 1 cuando no existe ninguna cubierta verde; el valor 0,5 se utiliza si se trata de una cobertura moderada, pero es posible utilizar valores intermedios, dependiendo de si la tendencia es a uno u otro extremo (Candiago et al., 2015). En este proyecto se seleccionó un $L=0,2$.

III. Equipamiento para la recolección y el procesamiento de imágenes agrícolas

La toma de imágenes aéreas en el espectro NIR e IR requiere de un VANT y un sensor multiespectral. El VANT seleccionado fue el USENSE-X8, equipo que cuenta con una sólida reputación de fiabilidad y robustez en el mercado. Es un vehículo del tipo ala fija, tiene un sistema del piloto automático basado en tecnología de código abierto y cuenta con un diseño que permite un funcionamiento flexible y una implementación segura en diferentes entornos y condiciones meteorológicas. La selección de este VANT fue validada con AZCUBA, la empresa azucarera del país. La cámara multiespectral seleccionada fue la Parrot Sequoia, un equipo que pesa solo 107 gramos y es muy potente y compacto. Tiene cuatro filtros para analizar nutrientes y biomasa de los cultivos y cuenta con una lente RGB de $16 \mathrm{mpx}$, que permite generar mapas con alto detalle, lo que es ideal para el conteo de plantas recién nacidas; posee además un sensor que capta la luz incidente, útil para guardar las condiciones de iluminación y calibrar los cuatro sensores multiespectrales, gracias al cual se pueden obtener índices de vegetación precisos, como los que se requieren en este proyecto.

IV. Procedimiento para la toma y el procesamiento de las imágenes multiespectrales

En general, el flujo de trabajo que posibilita la toma y el procesamiento de las imágenes multiespectrales (Figura 2) es el siguiente: Al recibir una solicitud del servicio, se estudia del área que se sobrevolara para la toma de las fotos, si el terreno presenta características desfavorables para el desarrollo de la misión, como grandes ondulaciones o fuertes vientos, la misión se descarta, de lo contrario se traza el plan de vuelo utilizando MissionPlanner; aceptada el área, se comprueba el estado del VANT y de la cámara multiespectral, si se presenta alguna where:

NIR $=$ spectral value of the near infrared band; and

green $=$ spectral value of the green band.

The GNDVI replaces the red band ( $\mathrm{R}$ ) for the data gathering process for NDVI; it performs this replacement with a very specific light band in the green range, entailing in the gathering of additional information. In opposition to indexes such as NDVI that cannot be determined without a red band, alternative indexes such as GNDVI have information content and similar value and they do not need this band (Gitelson, Kaufman, \& Merzlyak, 1996).

The gathering of frequent GNDVI allow the watering optimization and indicates when there is a lack of this resource or when it varies through the field. This information - together with a GPS - can be used to determine efficient solutions in some problematic areas of the crop, it also helps to provide application and correction material to make the fields more uniform relative to the water retention and usage. Furthermore, it also allows to implement an accurate variable rate diffusion technique (Dennis, Wright, \& Philip, 2003; Hunt et al., 2010).

Some alternative VI such as the SAVI (Huete, 1988)and the Optimized Soil Adjusted Vegetation Index [OSAVI] (Rondeaux, Steven, \& Baret, 1996) have been proposed to minimize the soil impact in the calculation of the VI in such areas where the vegetal coverage is poor and the soil surface is exposed. These variations are part of the vegetation indexes commonly used in remote sensing applications with the normalized vegetation index (Salamí, Barrado, \& Pastor, 2014; Trotter, Frazier, Trotter, \& Lamb, 2008; Hatfield \& Prueger, 2010). The SAVI varies in the ranges of -1 and 1 ; values trending to -1 correspond to a low coverage of the green vegetation and - as expected - values near 1 represent high coverage. Its calculation is made via Equation 3.

$$
S A V I=\frac{(N I R-R) *(L+1)}{N I R+R+L}
$$

where:

$\mathcal{N} I R=$ spectral value of the near infrared band;

$R=$ spectral value of the red band; and

$L=$ corrective factor of the soil reflectance.

It is important to mention that $L$ is a parameter with extreme values from -1 to 1 , where -1 is used in areas with a dense vegetation coverage; the 1 value is used when there is no green coverage in the terrain. The value of 0.5 is used for a moderate coverage, but it is possible to use intermediate values depending if the trend is going to one extreme or the other (Candiago et al., 2015). In this project, we used a value of $L=0,2$. 


\section{Equipment for the gathering and processing of agricultural images}

The gathering of aerial images in the NIR and IR spectrum requires a UAV and a multispectral sensor. The UAV we used was the USENSE-X8, which has a solid reputation relative to reliability and robustness in the market. It is a fixed-wing vehicle, it has an automatic pilot system based on open source technology, and it has a design allowing a flexible operation and a secure implementation under several environments and meteorological conditions. The selection of this UAV was validated with AZCUBA, the sugar company of the country. The selected multispectral camera was the Parrot Sequoia one with a weight of only 107 grams, making it a compact but powerful element. It has four filters to analyze nutrients and biomass of the crops and it also has an RGB lens of 16 megapixels. This last allow the generation of highly detailed maps, ideal for counting the small and sprout plants, it also has a sensor capturing the incident light, useful to store the illumination conditions and to calibrate the four multispectral sensors. These multispectral sensors allow the gathering of precise vegetation indexes such as the ones required for this project.

\section{Procedure for the gathering and processing of the multispectral images}

In general, the working flow that eases the gathering and processing of the multispectral images (Figure 2) is as follow: when receiving a service request, the area to overfly and take the photos is studied, if the terrain has unfavorable features for the development of the mission - such as large ruggedness or strong winds-, the mission is discarded; otherwise, the flight plan is traced using MissionPlanner. Once the area is accepted, the status of the UAV and of the multispectral camera are checked; if some issues arise, the possibility to fix them in the terrain is assessed and if this is not possible, the mission is cancelled. If both elements are ready and the weather conditions are good, the flight and the concurrent image gathering are performed; after, the information is extracted from the camera to preprocess it and the multispectral orthomosaic is generated by using Agisoft's Photo Scan. Finally, the vegetation indexes are calculated with the corresponding bands for each formula.

MissionPlanner - the software used to plan the flightis a ground control station with all the functions of the Multi-Platform Autopilot [MPA] open source project; it has an interface to establish the gain and damping of the vehicle following strategy, which is programmed in the ArduPilot (Hernández-Morales, Valeriano-Medina, Hernández-Julián, \& Hernández-Santana, 2017). It also proposes a series of cameras - included the one employed in this project- avería se valora su reparación en el terreno y, de no ser posible, se cancela la misión; si los dos elementos están listos y el clima es el idóneo, se realiza el vuelo y la toma de las imágenes multiespectrales; luego, se extrae la información de la cámara, se realiza el procesamiento previo y se genera, utilizando Photo Scan de Agisoft, el ortomosaico multiespectral, y hecho esto, se calculan los índices vegetativos con las bandas espectrales correspondientes a cada fórmula.

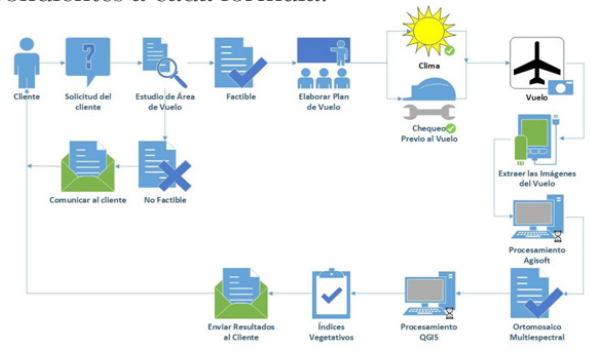

Figure 2. Workflow for the calculation of vegetation indexes Flujo de trabajo para el cálculo de los índices vegetativos

MissionPlanner, el software utilizado para planificar el vuelo, es una estación de control en tierra con todas las funciones de proyecto de piloto automático de código abierto APM [Multi Platform Autopilot]; provee una interfaz para establecer los parámetros de ganancia y amortiguamiento de la estrategia de seguimiento del vehículo, programada en el ArduPilot (Hernández-Morales, Valeriano-Medina, Hernández-Julián, \& Hernández-Santana, 2017) y propone una serie de cámaras, incluida la Sequoia empleada en este proyecto, a partir de las cuales calcula el recorrido del vuelo y la altura sobre el suelo a la que debe sobrevolar el VANT, lo que es fundamental para recolectar imágenes con la resolución adecuada.

En la pantalla del software se establecen los polígonos que serán fotografiados, la ruta a seguir por el VANT, las exigencias de solape de las fotos en la dirección del vuelo (longitudinal) y las paralelas al vuelo (transversal), así como la configuración de la cámara (Figura 3). En el proyecto, los vuelos se efectuaron a una altura de 40 metros y a una velocidad de 6 metros/segundo, obteniéndose un GSD [Ground Sample Distance] de 3 $\mathrm{cm} /$ pixel y un adecuado solape.

En este proyecto en particular, el terreno sobrevolado correspondió a un campo de caña de seis meses (periodo de gran crecimiento) sembrado con veinticinco variedades, en un diseño de bloques al azar en condiciones de secano, en un suelo

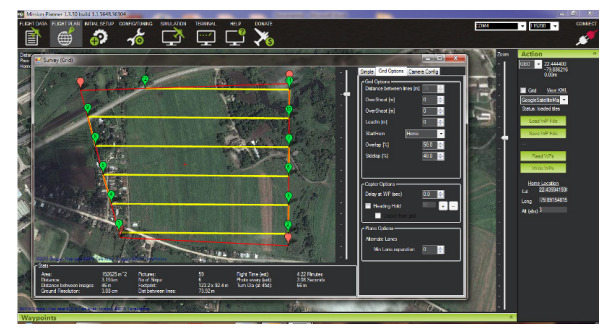

Figure 3. Planning screen of the MissionPlanner mission Pantalla de planificación de la misión del MissionPlanner 
vertisol pélico, bajo un clima tropical (propio del área geográfica cubana). Cada variedad ocupaba una parcela de $41 \mathrm{~m} 2(6,4$ x 6,4 m) formada por cinco surcos, con un surco de barrera en ambos laterales. La dosificación del campo fue de $212.76 \mathrm{Kg} /$ ha de superfosfato triple y $333.33 \mathrm{Kg} /$ ha de KCL.

La herramienta seleccionada para el cálculo de los IV mencionados fue QGIS v.2.4 [Quantum GIS], un Sistema de Información Geográfica [Geographical Information System, GIS] de código abierto para plataformas GNU/Linux, Unix, Mac OS, MSWindows y Android, que permite manejar formatos ráster y vectoriales a través de sus bibliotecas, y como bases de datos. $\mathrm{Al}$ ser de código abierto, permite la integración de plugins desarrollados en $\mathrm{C}++$ y Python. La versión utilizada incluye además soporte completo para procesamiento multihilos (se recomiendan procesadores de al menos cuatro núcleos). QGIS, a partir de la herramienta SAGA ToolBox, calcula los IV siguiendo esta secuencia:

- los datos multiespectrales, donde las bandas individuales son archivos ráster separados, se unifican en una pila de capas única que contenga todas las bandas;

- se carga la imagen apilada en capas en la herramienta de índices radiométricos del SAGA;

- se definen las bandas que se van a utilizar para calcular el índice;

- se selecciona el índice que se va a calcular (en este caso NDVI); y

- se realiza el cálculo del índice.

Las imágenes presentan tres bandas espectrales: la NIR, la verde y la roja, en ese orden. Primero se obtiene la imagen multiespectral del campo al que se le desea calcular el índice vegetativo (Figura 4) y luego se extraen las bandas espectrales que se van a utilizar, mediante la calculadora ráster (Figura 5), en este caso, la banda roja, la verde y la NIR, que son las nece-

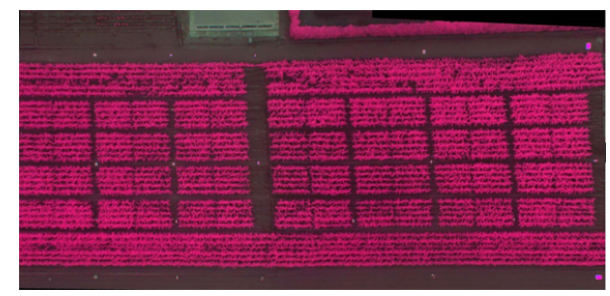

Figure 4. Multispectral image of the overflown field to calculate the vegetation indexes / Imagen multiespectral del campo sobrevolado para el cálculo de los índices vegetativos



Figure 5. QGIS's raster calculator to calculate the flight path and the altitude the UAV should fly, which is fundamental to obtain images with the adequate resolution.

The polygons to photograph, the flyby to follow, the picture overlapping requirements in the flight direction (longitudinal) and parallel to the flight (transversal), and the camera configuration (see Figure 3) are established in the software screen. In this project, the flights were performed at an altitude of 40 meters with a maximum speed of 6 meters per second; this led to a Ground Sample Distance [GSD] of $3 \mathrm{~cm} /$ pixel and an adequate overlapping.

In this particular project, the overfly terrain was a sugarcane plot with a plant age of 6 months (large growing period) sowed with 25 diversities in a random block design in a non-irrigated land condition. Furthermore, the soil was pellic vertisol under a tropical climate (typical of Cuba) and each diversity takes up to 41 square meters $(6.4 \times 6.4 \mathrm{~m})$ made by 5 furrows with a border furrow in each side. The field dosage was $212.76 \mathrm{~kg} / \mathrm{ha}$ of triple superphosphate and $333.33 \mathrm{~kg} / \mathrm{ha}$ of $\mathrm{KCl}$.

The tool selected for the calculation of the mentioned VIwas QGIS on its version 2.4[Quantum GIS] together withan open source GIS for GNU/Linux, Unix, Mac OS, Windows, and Android platforms, allowing to handle vector raster formats through its libraries and with databases. The fact of being an open source project allows the integrations of plugins developed in $\mathrm{C}++$ and Python. The employed version also has full support for multi-thread processing (processors with at least 4 cores are recommended). QGIS calculates the VI from the SAGA ToolBox following this sequence:

- The multispectral data — where the individual bands are separated raster files - are unified in a unique pile of layers having all the bands;

- the image stacked in layers is loaded in the SAGA radiometric indexes tool;

- the employed bands to calculate the indexes are defined;

- the index to use is selected (in this case is NDVI); and

- the calculation of the index is performed.

The obtained images present three spectral bands: NIR, green, and red (in this order). First, the multispectral image of the field where the VI will be calculated is obtained (Figure 4), after, the spectral bands to use are extracted via the raster calculator (Figure 5). In this case, our interest is in the red, green, and NIR bands, which are required to calculate the NDVI, GNDVI, and SAVI. Figure 4 corresponds to the multispectral image of the overflown sugarcane field at an altitude of 40 meters and a speed of 6 meters per second. The red pixels are cultivated parcels, whilst the dark sectors are zones without plants or correspond to soil. 


\section{Relation between the spectral re- flectance of the sown fields and the amount of sugarcane stalks}

In Figure 6, the reader can appreciate how the reflectance is low for plants in the red spectrum (a), larger in the green spectrum (b), and even more in the NIR (c). The NIR band is fundamental in the calculation of the indexes; if a transformation towards a space with colors is performed, it would be possible to appreciate the variation through the strength and vitality of the plants. The task is to create a precise prescription for the field considering these variations by calculating a vegetation index - in this case, NDVI-. The real NDVI image in gray scale is shown in Figure 7.

Frequently, this image is transformed to a "pseudo-color" format to ease its interpretation. For our case, the colors have the trend to follow the standard color spectrum where the purple areas are soil or zones with dry grass and the red zones show the vegetal sections (Figure 8). Both parts of Figure 8 ( $\mathrm{a}$ and $\mathrm{b}$ ) present a high correlation level between the studied crop type and the NDVI readings. On its initial growing stage, sugarcane has elevated chlorophyll levels and show high NDVI values within its fundamental reflectance features. In this experiment, the maximum obtained NDVI value was 0.94 , with an average of 0.7 ; which indicates a young and healthy crop. If the sugarcane had more time of being sowed, it would be in the ripening period and the NDVI values would be smaller. The high vegetal strength of the studied field and deducted from the NDVI image was validated by specialists in the terrain through the gathering and laboratory analysis of multiple samples This was done through the count in the number of stalks per parcel, and through the measurement of the sugarcane average height. Furthermore, we were able to observe the presence of weed in the furrows; it could be eliminated via the application of herbicides in the zones with larger grass reflectance. The image at the right (Figure 8b) shows a legend equivalent to a vegetation general coverage; hence, the NDVI values of the

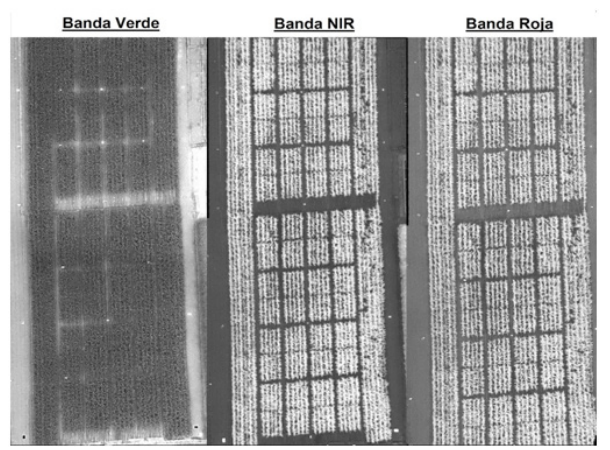

Figure 6. Spectral bands extracted from the multispectral image: red (a); green (b); y NIR (c) / Bandas espectrales extraídas de la imagen multiespectral: roja (a); verde (b); y NIR (c) sarias para los cálculos de NDVI, GNDVI y SAVI.

La Figura 4 corresponde a la imagen multiespectral del campo de caña sobrevolado a una altura de 40 metros y a una velocidad de 6 metros/segundo. Los pixeles rojos corresponden a parcelas cultivadas, mientras que los sectores oscuros a zonas con despoblamiento vegetal o suelo.

V. Relación entre la reflectancia espectral de los sembrados y la cantidad de tallos de caña de azúcar

En la Figura 6 se puede apreciar cómo la reflectancia es baja en las plantas en el espectro rojo (a), mayor en el espectro verde (b) y aún mayor en el NIR (c). La banda NIR es fundamental en el cálculo de los índices, si ella fuera transformada a un espacio con colores se podría apreciar la variación a través del campo de la vitalidad de las plantas. La tarea es crear una prescripción precisa para el campo sobre la base de estas variaciones, con el cálculo de un índice de vegetación, en este caso el NDVI. La imagen de NDVI real, en escala de grises, se muestra en la Figura 7.

A menudo esta imagen se transforma a pseudocolor para facilitar su interpretación. En este ejemplo, los colores siguen el espectro de color estándar en el que las áreas de color púrpura corresponden al suelo o a las zonas con pasto seco, y las zonas rojas muestran el mayor vigor vegetal (Figura 8). Las dos partes de la Figura 8 (a y b) presentan un nivel de correlación alto entre el tipo de cultivo estudiado y las lecturas del NDVI. La caña de azúcar en su periodo inicial de crecimiento posee elevados niveles de clorofila y muestra, entre sus características fundamentales de reflectancia, altos valores de NDVI. En este experimento, las lecturas máximas de NDVI fueron de 0,94, con una media por encima de 0,7 , lo que indica un cultivo de caña joven y saludable; si la caña tuviera mayor edad, estaría en período de maduración y por tanto mostraría valores de NDVI menores. El elevado vigor vegetal del campo presupuesto a partir de la imagen NDVI fue validado por especialistas en el terreno a través de la recolección y el análisis en el laboratorio de múltiples muestras vegetales, el conteo del número de tallos por parcela y la medición de la altura promedio de la caña. También se pudo apreciar la presencia de maleza en los surcos, la cual pudiera ser eliminada mediante la aplicación de herbicidas en las zonas de más alta reflectancia del pasto. La imagen de la derecha (Figura 8b) muestra una leyenda equivalente a una cobertura general de vegetación, con lo que se aprecia que los valores de NDVI de la caña joven son equivalentes a los que

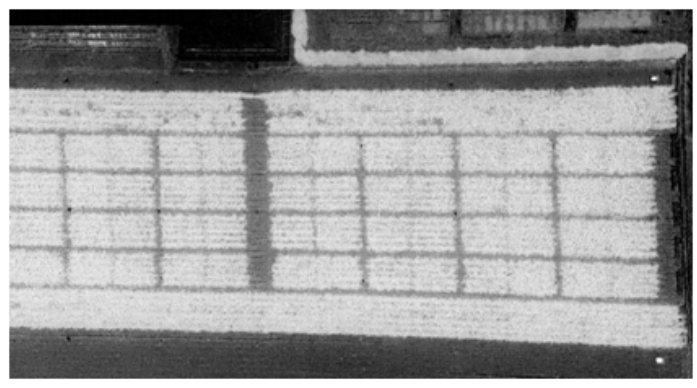

Figure 7. NDVI Image / Imagen NDVI 


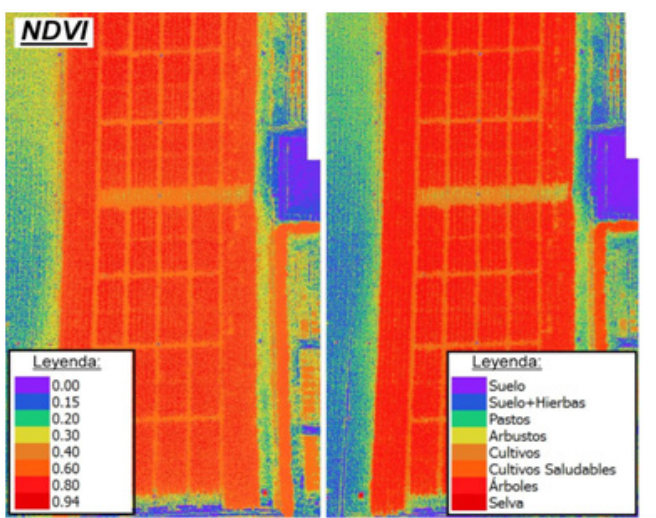

Figure 8. NDVI Orthophoto with predefined colors as per the scale generated by the software / Ortofoto NDVI con colores predefinidos según la escala generada por el software

poseen los árboles, según la literatura.

El NDVI se puede convertir en mapas de aplicación variable para el uso con equipos de granja que tengan la tecnología tasa variable, es decir que guiados por un GPS sean capaces de dosificar insumos, como los abonos a aplicar por cada tipo de zona. Un ejemplo es la aplicación de nutrientes en un solo campo, el agricultor puede aplicar 60 libras de fertilizante para las zonas con dificultades (verdes), 50 libras a las áreas medianas (amarillas) y 40 libras a las áreas sanas (amarillas-rojas), con ello, disminuiría los costos derivados del empleo de fertilizantes, reduciría la contaminación del manto freático y aumentaría los rendimientos.

Los suelos pueden influir negativamente en la calidad de la fotogrametría realizada a un cultivo debido a la reflectancia que tienen en la banda NIR del espectro. Para contrarrestar este error en la medición se utiliza el índice SAVI, que en este caso fue calculado con una $L=-0,2$ debido a que las plantaciones fotografiadas presentaban una vitalidad muy alta, como se aprecia en la Figura 9a (en 9b se muestra la leyenda equivalente a una cobertura general de vegetación).

Por último, se calculó el índice GNDVI, el cual aprovecha la diferencia existente entre las reflectancias Verde y el NIR de las plantas, y da lugar a una medición de un rango menor, pero relacionada estrechamente con su actividad fotosintética,

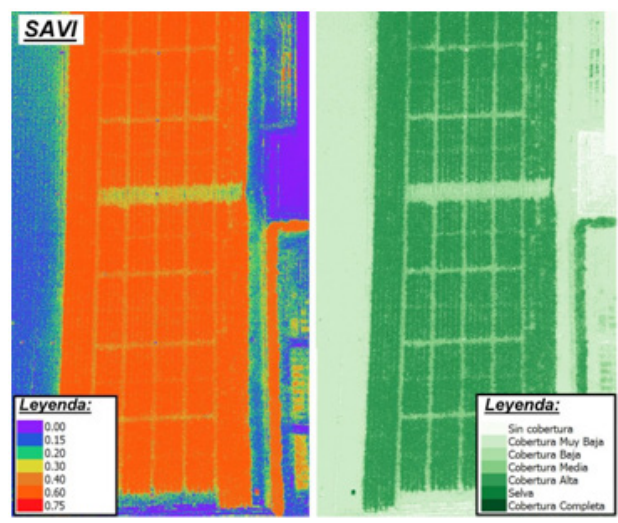

Figure 9. SAVI images with predefined colors as per the scale generated by the software / Imágenes SAVI con colores predefinidos según la escala generada por el software young sugarcane are similar to the ones that the trees have, as per the consulted scientific literature.

The NDVI can be converted into variable application maps for its usage with farm equipment supporting the so-called Variable Rate Technologies [VRT]; i.e., the machinery is able to ration supplies - such as fertilizers to apply per zone - by using a GPS. One example is the nutrients application in a single field, where the farmer can apply up to 60 pounds of fertilizer for the zones with difficulties (green), 50 pounds to the medium areas (yellow), and 40 pounds to the healthy sections (yellow-red). This will entail in a considerable reduction of the associated costs in the fertilizers usage plus the reduction in the contamination of the water-table layer, and it would increase the crop yield.

The soils can negatively affect in the quality of the performed photogrammetry to a crop due to the reflectance that they have in the NIR band of the spectrum. In order to counteract this measurement error, we used the SAVI index with the parameter $L=0.2$. This, since the photographed crops presented a high strength as Figure 9a depicts (Figure 9b shows the equivalent legend to a general vegetation coverage).

Finally, we calculated the GNDVI index; this index takes advantage of the existing difference between the green and NIR reflectance of plants and provides a measurement with less range but tightly related with its photosynthetic activity. This allows to perform several studies to the vegetation such as the case of detecting nitrogen lacks. In this case, the reading values were up to 0.5 with an average of 0.35 ; i.e., a good photosynthetic activity translated in a level within the standard nitrogen range in the plantation.

The relation between the maps with NDVI and GNDVI indexes and the number of sugarcane stalks per parcel was validated via the dispersion graphs on each experiment. Figures 11 and 12 correspond to dispersion graphs with the following values: $\mathrm{R} 2=0.702$ and $\mathrm{R} 2=0.685$ respectively. Both graphs were generated by using SPSS. On the other hand, the correlation between the SAVI maps for a value

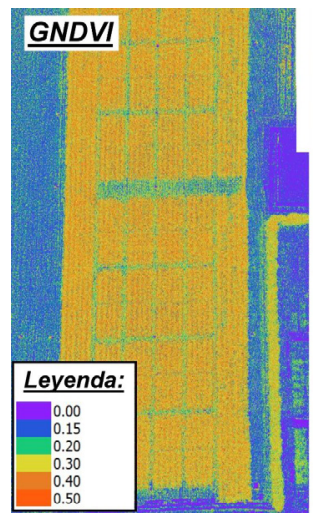

Figure 10. GNDVI images with predefined colors as per the scale generated by the software / Imágenes GNDVI con los colores predefinidos según la escala generada por el software 


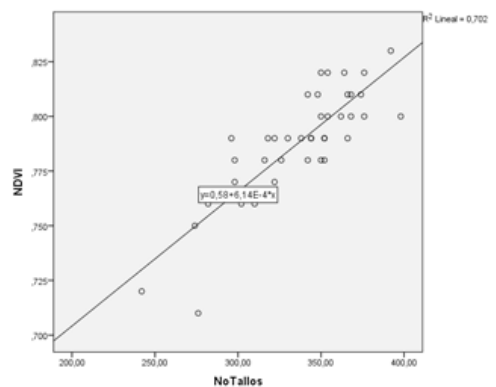

Figure 11. Dispersion graph(R2=0.702) -Correlation between the NDVI map and the number of stalks per parcel / Gráfico de dispersión (R2=0.702) - Correlación entre el mapa NDVI y el número de tallos por parcela

of $\mathrm{L}=0.2$ and the number of stalks was poor, i.e., the calculation of this index should be done again by reducing the value of L towards -1 (due to the high strength level of the sugarcane parcels) until getting better results. Nevertheless, given the high vegetal coverage level present in the field, the soil reflectance effect is not large; hence, the calculation of the SAVI index is not indispensable to minimize the impact of the soil in the calculation of the vegetation indexes.

The reader should consider that the $\mathrm{L}$ factor does not have any effect on the NDVI and GNDVI indexes - the ones showing a good correlation between them and the number of stalks per parcel-. Furthermore, it is important to focus that no more tests were carried out with different $\mathrm{L}$ values to modify the SAVI index, since the incidence of the soil in the reflectance is low, the calculation of the NDVI and GNDVI indexes is enoughto identify parcels with high vegetal density.

Besides, we performed some linear regressions between the NDVI and GNDVI indexes and the number of stalks in 25 parcels in order to assess the linear regression degree between these variables, as Table 1 shows. The selected method was the Kendall's rank correlation coefficient. Given the high Kendall Tau values obtained, we can affirm that these two indexes can be directly correlated with the amount of sugarcane stalks and indirectly with the agricultural production. The NDVI and GNDVI in-
Table 1. Kendall correlation between the NDVI and GNDVI indexes and the number of stalks per parcel / Correlación de Kendall entre los índices NDVI y GNDVI y el número de tallos por parcela

\begin{tabular}{|c|c|c|}
\hline \multirow{2}{*}{$\begin{array}{l}\text { Parcela } \\
(\#)\end{array}$} & \multicolumn{2}{|c|}{ Valor de la Tau de Kendall para... } \\
\hline & NDVI & GNDVI \\
\hline 1 & 0.725 & 0.681 \\
\hline 2 & 0.708 & 0.694 \\
\hline 3 & 0.741 & 0.725 \\
\hline 4 & 0.729 & 0.711 \\
\hline 5 & 0.746 & 0.727 \\
\hline 6 & 0.770 & 0.750 \\
\hline 7 & 0.748 & 0.730 \\
\hline 8 & 0.749 & 0.728 \\
\hline 9 & 0.762 & 0.750 \\
\hline 10 & 0.747 & 0.724 \\
\hline 11 & 0.770 & 0.761 \\
\hline 12 & 0.751 & 0.741 \\
\hline 13 & 0.790 & 0.774 \\
\hline 14 & 0.748 & 0.728 \\
\hline 15 & 0.771 & 0.760 \\
\hline 16 & 0.750 & 0.743 \\
\hline 17 & 0.760 & 0.748 \\
\hline 18 & 0.739 & 0.720 \\
\hline 19 & 0.800 & 0.783 \\
\hline 20 & 0.763 & 0.745 \\
\hline 21 & 0.749 & 0.726 \\
\hline 22 & 0.780 & 0.769 \\
\hline 23 & 0.766 & 0.750 \\
\hline 24 & 0.791 & 0.772 \\
\hline 25 & 0.762 & 0.741 \\
\hline
\end{tabular}

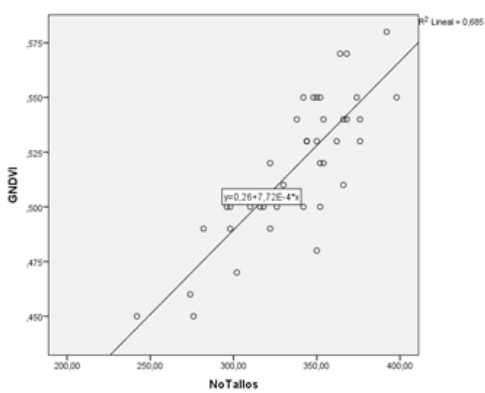

Figure 12. Dispersion graph(R2=0.685)- Correlation between the GNDVI map and the number of stalks per parcel / Gráfico de dispersión $(R 2=0.685)$ - Correlación entre el mapa GNDVI y el número de tallos por parcelas

que permite realizar diferentes estudios a la vegetación, como el caso de la detección del déficit de nitrógeno. En este caso, los valores de la lectura llegaron a 0,5 con una media de 0,35 , lo que muestra una buena actividad fotosintética, que se puede traducir también en un nivel dentro del rango estándar de nitrógeno en la plantación (Figura 10).

La relación entre los mapas de índices NDVI, GNDVI y el número de tallos de caña por parcela fue validada mediante los gráficos de dispersión de cada experimento. Las Figuras 11 y 12 corresponden a gráficas de dispersión, la primera con $\mathrm{R} 2$ $=0.702$ y la segunda con R2=0.685. Ambas gráficas se generaron utilizando SPSS. En cambio, la correlación entre los mapas SAVI para una $\mathrm{L}=-0.2 \mathrm{y}$ el número de tallos resultó bastante pobre, por lo que habría que replicar el cálculo de este índice, disminuyendo aún más el valor de la $\mathrm{L}$ hacia -1 (debido al elevado nivel de vitalidad de las parcelas de caña), hasta obtener mejores resultados. No obstante dado el elevado nivel de cobertura vegetal presente en el campo, el efecto de la reflectancia del suelo no es elevada, por lo que el cálculo del índice SAVI no es imprescindible para minimizar el impacto del suelo en el cálculo de los índices vegetativos.

Es importante no perder de vista que el factor L no tiene ningún efecto sobre los índices NDVI y GNDVI -los que mostraron una buena correlación entre cada uno de ellos y el número de tallos por parcela-. Cabe precisar además que no se realizaron más pruebas con otros valores de L para variar el índice SAVI ya que, al ser baja la incidencia del suelo en la reflectancia, bastaba con calcular los índices NDVI y GNDVI para poder identificar parcelas con elevada densidad vegetal.

También fueron realizadas regresiones 
lineales entre los índices NDVI y GNDVI y el número de tallos de veinticinco parcelas, con el fin de evaluar el grado de relación lineal entre estas variables del experimento, como se muestra en la Tabla 1. El método seleccionado fue el de Coeficiente de Correlación por Rangos de Kendall. Dados los elevados valores de Tau de Kendall obtenidos, se puede afirmar que estos dos índices pueden correlacionarse directamente con la cantidad de tallos de caña de azúcar e indirectamente con la producción agrícola. Los mapas de índices NDVI y GNDVI permitieron además identificar puntualmente las parcelas con una media de tallos por debajo del resto de parcelas del campo. Conclusiones y trabajo futuro

Las ortofotos NDVI y GNDVI generadas a partir de las fotografías de la cámara Sequoia permitieron identificar parcelas de caña de azúcar con una elevada densidad y vigor vegetal, resultados que se corroboraron en el terreno a través de la recolección y el análisis en el laboratorio de múltiples muestras vegetales, el conteo del número de tallos por parcela y de la altura promedio de la caña. De esta manera, se puede afirmar que los VANT representan una excelente herramienta para la evaluación de sembrados de caña de azúcar, por la facilidad de montar cámaras multiespectrales y de obtener imágenes de alta resolución representadas en 3,0 cm/pixel.

Los mapas de índices obtenidos permiten identificar problemas de crecimiento en los surcos y tomar medidas en áreas puntuales de los cultivos, lo que puede disminuir el tiempo y trabajo, no solo en zonas de difícil acceso, sino también en grandes extensiones cañeras. La identificación, a partir de la respuesta espectral, de parcelas de caña con una baja densidad vegetal, facilita a los directivos agrícolas el diseño de estrategias de dosificación variable de fertilizantes dependientes de las necesidades de los sembrados, con miras a la homogenización del rendimiento y la calidad.

Con el fin de mejorar los resultados obtenidos en las zonas cultivadas, se observa la necesidad de realizar estudios complementarios que incorporen variables tales como el análisis de suelos, que soporten la identificación de zonas de respuesta espectral específica, monitoreo en diferentes períodos de tiempo y supervisión de la evolución de las zonas detectadas según las medidas correctivas aplicadas.SET dex maps also allowed the punctual identification of the parcels with an average of stalks under the rest of the parcels.

\section{Conclusions and Future Work}

The NDVI and GNDVI orthophotos generated from the photographs of the Sequoia camera allowed to identify sugarcane parcels with a high density and vegetal strength, results that were corroborated in the terrain through the gathering and laboratory analysis of multiple vegetal samples and through the count of the number of stalks per parcel and average sugarcane height. Consequently, it is possible to affirm that the UAV represents an excellent tool for the evaluation of sugarcane crops due to the ease in mounting multispectral cameras and obtaining high-resolution images represented in $3 \mathrm{~cm} /$ pixel.

The obtained index maps allowed us to identify growing problems in the furrows and take actions in punctual areas of the crop, which can reduce the time and work not only in hard-to-reach working zones, but also in large sugarcane plantations. The identification of sugarcane parcels with a low vegetal density from the spectral response ease the farmers the design of fertilizing variable dosage strategiesdepending of the sowing needs. This seeking towards the homogenization of performance and quality.

In order to improve the obtained results in the cultivated zones, the need to perform complementary studies including variables such as the soil analysis supporting the identification of specific spectral response zones has arisen. Furthermore, studies about the monitoring in different period of times and supervision in the evolution of the detected zones as per the corrective measurements applied is also another need that has appeared. $\mathbf{S C}$ 


\section{References / Referencias}

Bachmann, F., Herbst, R., Gebbers, R., \& Hafner, V.V. (2013). Micro UAV based georeferenced orthophoto generation in VIS+NIR for precision agriculture. In: Proceedings of the UAV. Remote Sensing and Spatial Information Sciences, (Vol. 40. pp. 11-16).

Basso, B. (2014). Perspectivas y avances del uso de UAV en AP en USA. Retrieved from: https://inta.gob.ar/sites/default/files/ script-tmp-inta_g1-perspectivas_y_avances_del_uso_de_uav_en_ap_e.pdf

Best, S. \& Zamora, I. (2008). Tecnologías aplicables en agricultura de precisión: uso de tecnología de precisión en evaluación, diagnóstico y solución de problemas productivos. Santiago de Chile: Fundación para la Innovación Agraria.

Best, S., León, L., \& Claret, M. (2005). Use of precision viticulture tools to optimize the harvest of high quality grapes. Proceedings of the fruits and nuts and vegetable production engineering TIC (Frutic05), (pp. 249-258).

Campo, L., Corrales, J. \& Ledezma, A. (2015). Remote sensing for agricultural crops based on a low cost quadcopter. Sistemas \& Telemática, 13(34), 49-63. doi:10.18046/syt.v13i34.2092

Candiago, S., Remondino, F., De Giglio, M., Dubbini, M., \& Gattelli, M. (2015). Evaluating multispectral images and vegetation indices for precision farming applications from UAV images. Remote Sensing, 7(4), 4026-4047.

Chuvieco, L. (2000). The use of qualitative airbone multispectral imaging for managing agricultural crops: a case study in South- Eastern Australia. Aust. J. Exp. Agric, 40, 725-738.

Dennis, L., Wright, J. \& Philip, R. (2003). Managing protein in hard red spring wheat with remote sensing [paper in The 6th Annual National Wheat Industry Research Forum, 2003. Retrieved from: https://www.researchgate.net/publication/252140884_Managing_Grain_Protein_in_Wheat_Using_Remote_Sensing

Gago, J., Douthe, C., Coopman, R., Gallego, P., Ribas-carbo, M., ... \& Medrano, H. (2015). UAVs challenge to assess water stress for sustainable agriculture. Agricultural Water Management, 153, 9-19.

García, C. \& Herrera, F. (2015). Percepción remota en cultivos de caña de azúcar usando una cámara multiespectral en vehículos aéreos no tripulados [paper in: Anais XVII Simpósio Brasileiro de Sensoriamento Remoto-SBSR. Retrieved from: http://www.dsr.inpe.br/sbsr2015/files/p0873.pdf

Gitelson, A. A., Kaufman, Y. J., \& Merzlyak, M. N. (1996). Use of a green channel in remote sensing of global vegetation from EOS-MODIS. Remote sensing of Environment, 58(3), 289-298.

Guo, T., Kujirai, T.. \& Watanabe, T. (2012). Mapping crop status from an unmanned aerial vehicle for precision agriculture applications. In: International Archives of the Photogrammetry, Remote Sensing and Spatial Information Sciences, (Vol. 39-B1 pp.485-490). ISPRS.

Gutierrez-Rodriguez, M., Escalante-Estrada, J. A., \& Rodriguez-Gonzalez, M. T. (2005). Canopy reflectance, stomatal conductance, and yield of Phaseolus vulgaris L. and Phaseolus coccinues L. under saline field conditions. Int. J. Agric. Biol, 7 , 491-494.

Hatfield, J. L. \& Prueger, J. H. (2010). Value of using different vegetative indices to quantify agricultural crop characteristics at different growth stages under varying management practices. Remote Sensing, 2, 562-578.

Hernández, L., Rodríguez, E., Martínez, A., Álvarez, H., Kharuf, S., \& Morales, L. H. (2016). Levantamiento fotogramétrico de la UBPC “Desembarco del Granma” utilizando aviones no tripulados, solución de bajo costo para la agricultura nacional. In: VII Edición de la Conferencia Científica Internacional sobre Desarrollo Agropecuario y Sostenibilidad 2016. Santa Clara, Cuba: UCLV.

Hernández-Morales, L., Valeriano-Medina, Y., Hernández-Julián, A. \& Hernández-Santana, L. (2017). Estudio sobre la estrategia de guiado L1 para el seguimiento de caminos rectos y curvos en UAV. Ingeniería Electrónica, Automática y Comunicaciones, 38, 14-25

Huete, A.R. (1988). A soil-adjusted vegetation index (SAVI). Remote Sensing of Environment, 25, 295-309.

Hunt, E. R., Hively, W. D., Fujikawa, S. J., Linden, D. S., Daughtry, C. S., \& McCarty, G. W. (2010). Acquisition of NIR-greenblue digital photographs from unmanned aircraft for crop monitoring. Remote Sensing, 2, 290-305.

Johansen, K., Sallam, N., Robson, A., Samson, P., Chandler, K., Derby, L., ... \& Jennings, J. (2018). Using GeoEye-1 Imagery for Multi-Temporal Object-Based Detection of Canegrub Damage in Sugarcane Fields in Queensland, Australia. GIScience \& Remote Sensing, 55(2), 285-305.

Lofton, J., Tubana, B. S., Kanke, Y., Teboh, J., Viator, H., \& Dalen, M. (2012). Estimating sugarcane yield potential using an in-season determination of normalized difference vegetative index. Sensors, 12, 7529-7547.

Lopes, M. S. \& Reynolds, M. P. (2012). Stay-green in spring wheat can be determined by spectral reflectance measurements (normalized difference vegetation index) independently from phenology. Journal of Experimental Botany, 63, 3789-3798.

Marote, M. (2010). Agricultura de Precisión. Ciencia y Tecnología, 10, 151.

Martínez, L. J. (2017). Relationship between crop nutritional status, spectral measurements and Sentinel 2 images. Agronomía Colombiana, 35, 205-215.

Pettorelli, N., Vik, J. O., Mysterud, A., Gaillard, J. M., Tucker, C. J., \& Stenseth, N. C. (2005). Using the satellite-derived NDVI to assess ecological responses to environmental change. Trends in Ecology \& Evolution, 20(9), 503-510.

Rondeaux, G., Steven, M., \& Baret, F. (1996). Optimization of soil-adjusted vegetation indices. Remote Sensing of Environment, 55(2), 95-107.

Salamí, E., Barrado, C., \& Pastor, E. (2014). UAV flight experiments applied to the remote sensing of vegetated areas. Remote Sensing, 6(11), 11051-11081

Saxena, L., \& Armstrong, L. (2014). A survey of image processing techniques for agriculture. In: Proceedings of Asian Federa- 
tion for Information Technology in Agriculture (pp. 401-413). Perth, W.A: Australian Society of Information and Communication Technologies in Agriculture. Retrieved from: https://ro.ecu.edu.au/ecuworkspost2013/854

Torres, A., Gómez, A., \& Jiménez, A. (2015). Development of a multispectral system for precision agriculture applications using embedded devices. Sistemas \& Telemática, 13(33), 27-44. https://doi.org/10.18046/syt.v13i33.2079

Trotter, T. F., Frazier, P., Trotter, M. G. \& Lamb, D. W. (2008). Objective biomass assessment using an active plant sensor (Crop Circle), preliminary experiences on a variety of agricultural landscapes [white paper]. Retrieved from: https://www. researchgate.net/profile/Paul_Frazier2

Vibhute, B. S. \& Bodhe, S. K. (2012). Applications of Image Processing in Agriculture: A Survey. International Journal of Computer Applications, 52, 34 - 40.

Virlet, N., Costes, E., Martinez, S., Kelner, J. J., \& Regnard, J. L. (2015). Multispectral airborne imagery in the field reveals genetic determinisms of morphological and transpiration traits of an apple tree hybrid population in response to water deficit. Journal of Experimental Botany, 66(18), 5453-5465.

Zhao, Y., Della-Justina, D., Kazama, Y., Rocha, J., Graziano, P., \& Camargo, R. (2016). Dynamics modeling for sugar cane sucrose estimation using time series satellite imagery. In: Proceedings of the Remote Sensing for Agriculture, Ecosystems, and Hydrology XVIII (pp. 99980J). International Society for Optics and Photonics. https://doi.org/10.1117/12.2242490 


\section{CURRICULUM VITAE}

Samy Kharuf Gutierrez Automation Engineer from the Universidad Central "Marta Abreu" de Las Villas [UCLV] (Cuba, 2014). He is a professor at the Department of Automation and Computer Systems from the UCLV's Faculty of Engineering and member of its Automation, Robotics and Perception Group [GARP]. His areas of professional interest include: multispectral image processing, modeling and control and guidance of unmanned vehicles / Ingeniero en Automática de la Universidad Central "Marta Abreu" de las Villas [UCLV] (Cuba, 2014). Docente del Departamento de Automática y Sistemas Computacionales de la Facultad de Ingeniería de dicha universidad y miembro del Grupo de Automatización, Robótica y Percepción [GARP]. Sus áreas de interés profesional incluyen: procesamiento de imágenes multiespectrales, modelado y control y guiado de vehículos no tripulados.

Rubén Orozco Morales Engineer in Electronics, Master in Telecommunications (1994) and Ph.D., in Technical Sciences (1998) from the Electrical Engineering School of the Universidad Central de Las Villas (Santa Clara, Cuba). He is a professor at the Department of Automation and Computer Systems of the Faculty of Engineering of the same university and member of the Automation, Robotics and Perception Group [GARP]. His areas of professional interest include image analysis and recognition of patterns in images / Ingeniero en Electrónica, Máster en Telecomunicaciones (1994) y Doctor en Ciencias Técnicas (1998) de la Facultad de Ingeniería Eléctrica de la Universidad Central de Las Villas (Santa Clara, Cuba). Docente del Departamento de Automática y Sistemas Computacionales de la Facultad de Ingeniería de dicha universidad y miembro del Grupo de Automatización, Robótica y Percepción [GARP]. Sus áreas de interés profesional incluyen el análisis de imágenes y el reconocimiento de patrones en ellas.

Osmany de la C. Aday Díaz Ingeniero Agrónomo en la Universidad Central de Las Villas (Santa Clara, Cuba) y Doctor en Ciencias Técnicas (2015) de la Universidad Agraria de la Habana "Fructuoso Rodríguez Pérez". Actualmente trabaja en la Estación Territorial de Investigaciones de la Caña de Azúcar (Santa Clara). Su área de interés profesional es la sanidad vegetal / Agronomics Engineer from the Universidad Central de Las Villas (Santa Clara, Cuba and PhD in Technical Sciences (2015) from the Universidad Agraria de la Habana "Fructuoso Rodríguez Pérez". He works for ETICA the main research entity in matters related with sugar cane in Cuba. His main area of professional interest is vegetal sanitation.

Emma Pineda Ruiz Agronomics Engineer from the Universidad Central de Las Villas (Santa Clara, Cuba, 1981) and PhD in Technical Sciences (2002). She works for ETICA the main research entity in matters related with sugar cane in Cuba. Her main area of professional interest is the edaphology / Ingeniera Agrónoma de la Universidad Central de Las Villas (Santa Clara, Cuba, 1981) y Doctora en Ciencias Técnicas (2002). Actualmente trabaja en la Estación Territorial de Investigaciones de la Caña de Azúcar [ETICA] (Santa Clara). Su interés profesional está centrado en la edafología. 